\title{
An Evaluation of the pre- service English teacher education in a university in China: Pros and cons from an insider's journey of learning
}

Wang Ping

Abstract: The theme of the paper is to reveal how well-prepared pre-service teachers think they are. It aims at reviewing the 2010, 2011, 2012, 2013 cohorts studying for a BA in TEFL at a university by examining the impact and the effectiveness of four-year pre-service English education in a Chinese university context, and what needs to be improved and maintained from the perspective of trainees. Questionnaires were used, followed by semi-structured interviews. The questionnaires were completed by 300 participants, 200 of whom were then randomly chosen as interviewees. Despite finding some inconsistency in the four-year BA TEFL program, the result obtained from investigation of the cohort of student teachers is still satisfying.

Key words: evaluation, insiders' perspective, BA English education programs, a university in China.

\section{Introduction and Background}

In 2001, as a result of the global expansion of English teaching through young learner programs, and China's rapid social and economic change, the Ministry of Education of China (MoE) initiated a curriculum innovation: the introduction of English as a foreign language in primary schools from Year 3 (ages 9-10) in most parts of China, and in more economically developed areas the opportunity to start learning English in Year 1. According to the 
Educational Statistics Yearbook of China 2014, in that year there were 0.47 million primary school English teachers and $76.67 \%$ of them were still unqualified. A shortage of qualified and competent English teachers has had a negative impact on the quality of English teaching in primary schools. The impact of teacher shortages is much greater in rural communities. Consequences include the inability to offer classes in English. The greatest problem is that this is most likely to impede on children's ability to qualify for secondary school English education. Perhaps most importantly, teacher shortages may reduce teacher quality in poor and remote areas. In rural areas of China, certified English teachers are difficult to recruit and retain. An informal survey conducted by teacher trainers He and He (2012) in Jiujiang Area, Jiangxi Province, showed that of the 1,100 primary school teachers $84.12 \%$ were non-English majors, who had majored in mathematics or Chinese or other subjects instead. Pre-service training in Teaching English as a Foreign Language (TEFL) for primary schools has obviously lagged behind the nation's economic development.

In 2002, the MoE formulated Standards for Teachers of English in Primary Schools (STEPS). They require all primary teachers to transform their views on teaching, to develop students' global language competence by making learning a process during which students develop language proficiency, form positive attitudes, improve thinking skills, increase cross-cultural awareness and learn to use learning strategies so as to gradually become independent learners. Comparably speaking, the greatest change is the shift from traditional grammar-translation to the development of overall language competence. The emphasis in STEPS lies on activating students' interest in learning English, relating the course content to the students' life experiences, promoting cooperation among students and advocating learning by doing. The implementation of STEPS has become a challenge for those who teach English in primary schools in China. In brief, in China, the current era of educational reforms aims to bring about a shift toward more student-centered English teaching and learning, a greater emphasis on critical thinking and the application of skills, and the establishment of a more democratic classroom environment (MoE, 2002).

In 2003, MoE launched a nationwide Bachelor of Arts (BA) program in TEFL, aiming to boost elementary English education in comprehensive universities in China. As a result, in September of that year, $74 \%$ of universities across China received their first cohort of student teachers for the BA TEFL English. The aim is that the BA program will supply the teaching force for elementary English language education. By 2007, the first four years of 
pre-service education had come to an end. This study investigated the four cohorts who completed the BA program in 2010, 2011, 2012, and 2013.

In the four year BA program, the compulsory taught courses include General English, Advanced General English, English Grammar, English Listening, English Speaking, English writing, Translation, Extensive Reading, English Listening, British Culture and Society, British and American Literature, Psychology, Basic Principles of Education, English Teaching Methodology, Testing (including TEMs design or teaching for TEM tests), and Concise Linguistics. The cohorts had a three month practicum in 20 local primary schools in their final year of the program. During the four years they were required to sit TEMs: the Test for English Majors Band 4 (TEM-4) and the Test for English Majors Band 8 (TEM-8), which are mandatory for English majors. For these students, passing TEM-4 is a graduation requirement. The test should be taken by the end of the second academic or sophomore year. TEM-8 is the highest level for English major students, so it should be taken during the end of the last academic or senior year. If an English-major student passes TEM-4 during his/her sophomore year, he/she may attempt to pass the TEM-8 during his/her senior year.

As pre-service teacher qualities and classroom performance have farreaching effects on the development of the English competence and performance of school pupils, it is important to pay special attention to pre-service English teacher programs and also to assess the impact of the BA TEFL program so that possible suggestions can be made to improve pre-service teacher training after the four-year pre-service English teacher education program is examined. In China, TEM-4 and TEM- 8 are used to gauge fouryear-program student improvement in those majoring in English. TEM-4 requires a vocabulary of 8000 items, which can be an indication of the relative level of English language proficiency. Those taking it are expected to complete examination tasks such as listening, dictation, grammar and vocabulary, reading, and essay writing in 140 minutes, which can show that the four-years training the respondents have received at the university is of great help in increasing their linguistic knowledge and shows the extent of their English language improvement. Those taking TEM-8 need a vocabulary of around 10,000 to 12,000 words to be able to tackle the test questions. The 210-minute test covers tasks such as listening, proofreading and error correction, reading, translation and essay writing. The tests are completed on the same day in a morning and an afternoon sitting, and the test is widely recognized throughout China. 
The research in this study was performed on a large cohort of college students who enrolled in the four-year BA TEFL program in 2010, 2011, 2012 and 2013 and aims to answer the following research question:

Was the implementation of four-year BA TEFL programs able to produce a valid representation of pre-service English teacher training for China's teacher education in comprehensive universities? If yes, to what extent? If not, what was the major concern?

In the article we also propose some ideas on how such programs in international EFL education could be developed and improved.

\section{Literature Review}

\section{EFL teacher training content: Factors to consider}

The literature on English-teacher preparation programs since the 1990s is quite extensive. Most of it focuses on training content; Johnson and Golombek (2011), for instance, consider teacher education as part of the activity of learning to teach. Wedell (1992) pays attention to how the balance of TEFL programs is distributed between linguistic, pedagogic and managerial competence. Richards (2009) proposes a scheme made up of ten types of knowledge (language proficiency factor, content knowledge, teaching skills, contextual knowledge, teacher's identity, learner-focused teaching, theoretical knowledge, subject matter knowledge, pedagogical reasoning skills, and decision-making skills). This contrasts with views of the knowledge base for teaching, which see it exclusively in terms of external knowledge which teachers must acquire and then apply. Bartolome (1994) states the importance of how well the training course prepares teachers for the classroom teaching which pre-service EFL teachers function in and the socio-cultural context they will work in after completing the training. Cosgun-Ogeyik (2009) focuses on studies of how language improvement courses are dealt with in the EFL teacher education curriculum.

Some scholars (e.g. Freeman, 1996; Freeman, \& Johnson, 1998) call for the development of the important area of trainee enquiry. Crandall (1993) stresses trainee flexibility in choice of teaching method. Furlong (2000), Smith and Reid (2000) and Williams and Soares (2002) all suggest that if trainee teachers are to understand pedagogy and the management of children's learning, they need to be encouraged in the university environment to "think more deeply about the educational purposes underlying their teach- 
ing" (Furlong, 2000, p. 6). Andrews (2007, p. ix) states that "the possession of an adequate level of Teacher Language Awareness is an essential attribute of any competent L2 teacher".

Ball (1999) and Brookes (2005) consider the issue of how employment based routes into teaching are in danger of making initial teacher education "pedestrian and utilitarian, eliminating emotion and desire from teaching" (Brookes, 2005, p. 49).

\section{EFL teacher training program evaluations}

Richard (1990), Reid (1996), and Wallace (1991) point out the importance of having a systemic evaluation at the heart of a pre-service teacher education program. Erozan (2005) Erozan (2005) uses reflective portfolios to evaluate language improvement courses in a pre-service English teacher education program. To investigate the effectiveness of pre-service teacher training approaches, Minott and Young (2009) adopt reflective journals to evaluate a pre-service teacher education program and develop the idea of a hybrid evaluation approach. Darling-Hammond (2006) and Schwile and Dembele (2007) emphasize the benefits of using a hybrid evaluation approach to evaluating a pre-service teacher program which can identify the best practice achieved in linking theory and practice in the training process. Their approach includes strong involvement from university staff and well-designed in-field experiences through action research and performance assessments. Seferoglu (2006) echoes Darling-Hammond and Schwile \& Dembele and carries out a qualitative study of teachers' opinions about the methodology and practice component of the pre-service teacher education program.

Roberts (1988) argues there is a need to identify clear questions and plan evaluations carefully and provides a detailed examination of English language to adults program in Tokyo. His reflective description of one such program is particularly useful, providing a balanced view of the program's strengths and weaknesses. Chong and Cheah (2009) conduct their study of a pre-service TEFL teacher program in Singapore. Based on data Chong and Cheah collected from final year student teachers, they conclude that while the framework of values, skills, and knowledge provided the graduating student teacher with maxims of teaching and learning, it was taught in isolation from practical implementation. They claim that would-be teachers should see their initial teacher education as the start of a continuum of professional learning and they need to develop a problem-solving attitude and the skills necessary to learn from experience through reflection. 
Peacock (2009) argues that evaluating the program is the starting point for the professionalization of ELT, and also contributes to program improvement. Peacock develops an evaluation model which is based on a comprehensive list of fifteen questions that arise from the relevant literature and which encourage the researcher to collect valuable information from various program stakeholders. The fifteen questions relate to evaluations of the philosophy of the program, of encouraging trainee flexibility, of fostering the trainees' ability to use and adopt the teaching materials, of experimental knowledge, of the trainees' current and future reflective teaching skills and ability, of promoting post-qualification teacher growth and development, of good linkage between the various courses, of the student-centered learning concept, of trainees' ability to function in the socio-cultural context they will work, of incorporating and balancing linguistic, pedagogic and managerial competence to appropriate degrees, of the degree of how up-to-date it is, and the satisfaction of trainees' needs. The data-collection instruments in his model work very well in the Hong Kong context and he later claims that his model could facilitate and encourage the evaluation of other teacher education programs in other contexts.

\section{Problems identified in the EFL teacher training program evaluation}

In the Chinese local context, in an attempt to reveal the strong and weak points of a BA pre-service English program in universities in China from the perspective of students, Han (2010) uses a questionnaire survey to collect data to analyze the present situation of pre-service TEFL education for English teaching and its influence on the teaching in the future. Zou (2009) tries to find out the causes of the poor quality of a BA English education program and make suggestions for future reform. Through semi-structured interviews and other techniques, he finds that the teachers lack academic knowledge, an ability to evaluate students and conduct effective teaching. This shows that although pre-service education is conducive to improving English teaching skills, the effect is not very noticeable (Wei, \& Pecheone, 2010).

Surveying the relevant literature, first of all, shows that there are a limited number of empirical studies on four-year pre-service BA TEFL teacher education in China. Not much has been researched or written with respect to the evaluation of such programs. Secondly, Han's and Zou's research provide us with an incongruous result for the pre-service English education program. This inconsistency or incongruity in Han's and Zou's leads me to investigate a pre-service English teacher program. 


\section{Methodology}

Combining qualitative and quantitative methods "has the potential of providing an alternative to validity through which the findings from one approach might have a chance of being validated by data from another" (Flick, 1998, p. 230).

\section{Mixed methods}

Mixed methods applies to research that combines qualitative and quantitative approaches within a single research project. This relates to Lim and Hang's (2003, p. 59) argument that using multiple sources of evidence can develop "converging lines of inquiry" and the finding or conclusion is likely to be "more convincing and accurate if it is based on several different sources and perspectives of information." The mixing of methods can be a valuable research strategy for several reasons (Denscombe, 2010): first, researchers can improve the accuracy of their findings by using different methods to investigate the same subject; second, a fuller and more complete picture of the phenomenon can be provided; third, it can compensate for the weaknesses of different methods; fourth, within this strategy contrasting methods can develop the analysis, with one method being used to inform another; finally, information from one method can be used as an aid to sampling: selecting a sample of people who will participate in the research through other different or contrasting methods.

This study relies mostly on quantitative data for considerations of its reliability and validity, which are regarded as the key tests in judging the adequacy of research. Reliability is regarded as "a synonym for consistency and reliability over time, over instruments and over groups of respondents" (Cohen et al., 2011, p. 117) and is associated particularly with quantitative research (Bryman, 2008).

\section{Questionnaire survey}

Questionnaires allow us to gather information that college EFL learners are able to report about themselves, such as beliefs and motivations about the learning and their reactions to learning (Mackey, \& Gass, 2005). In this study, with regard to the first and second research questions a questionnaire survey was felt to be appropriate since it can be used to collect, to code and to analyze data on a certain scale. It was intended that the survey would be used as a basis for providing a brief description of the effectiveness of the course in preparing students not about how a particular body used the BA 
to implement a program. Respondents' answers to the questionnaires would also provide a better sense of focus in terms of the key issues associated with the follow-up interviews.

The questionnaire was designed in English. The drafting of the questionnaire was a long and careful process. We referred to some scholars' (Han's, 2010; Wei, \& Pecheone, 2010; Zhou's, 2012) questionnaires and then designed it. In order to check understanding of the questions from the participants' point of view, a draft was sent for piloting to 10 college students who were studying at the same university as the participants of the study. They first completed the questionnaire, and then offered valuable suggestions for improvement (e.g. time needed for completion, the length of the questionnaire, the words used in each question, etc.). Two types of questions were mainly used in the questionnaire, closed and multiple-choice questions. No open questions were used because the feedback from the pilot study participants indicated that this type of question would place too great a demand on the respondents in terms of time and energy, thus affecting the return rate. Semi-structured interviews

As a research method, interviews are seen as being able "to gain explanations and information on material that is not directly accessible: perceptions, attitudes and values, matters which are difficult to obtain by alternative methods"(Partington, 2001, p. 33) and to "explore areas of broad cultural consensus and people's special understanding"(Denscombe, 2010, p. 4).

In this study, the data were collected through the survey of 300 pre-service TEFL students and by conducting follow-up interviews with 200 students. The face-to-face semi-structured interviews were used individually because they might yield information on the students' perceptions towards the program; the face-to-face semi-structured interviews also allowed the interviewer to gain feedback on the implementation of the BA program and explanations of relevant program policies adopted. Moreover, in the interview, the interviewees were more likely to answer the questions in their own words, and the interviewer could respond using prompt questions to elicit clarification or to encourage the interviewees to expand on their answers. Thus, the semi-structured interviews helped us obtain a variety of the kind of information we needed to answer the research question This level of detailed description, whether verbal or nonverbal, can show an otherwise hidden interrelatedness between emotions, people, objects unlike many quantitative methods of research (Weiss, 1994). 
Although semi-structured interviews potentially have great exploratory power in exploring in some depth people's viewpoints or opinions, interviewing people always takes a lot of time. In addition, interviewing requires skill on the part of the interviewer, for "an interview is not a conversation"(Drever, 1995 , p. 4). A second concern in relation to interviews is data quality. In order to establish empathy and rapport with the interviewees, the researcher prepared small gifts and tried to accommodate interviews' preferences (e.g. the time and venue they preferred). At the same time, all the interviews were recorded with a digital audio-recorder for later data sorting and analysis.

\section{Participants}

There were 300 BA TEFL students involved in the questionnaire investigation, of whom 170 were female and 130 were male. Their ages ranged between 22 and 25. The students were from the 2010 cohort (number of students: 75), 2011 cohort (number of students: 75), 2012 cohort (number of students: 75), and 2013 cohort (number of students: 75).

Two hundred were randomly selected from the 300 and interviewed. Of the 200 student teachers, 90 of them were male students and the rest were female. The data were collected through quantitative and qualitative data collection instruments. Questionnaires, semi-interviews and SPSS (19.0) document analysis were used in order to triangulate the data. The investigation research was conducted in a foreign language college in a university in China. The university was created by merging 5 colleges and was approved by the Ministry of Education in 2003. It is funded by both the provincial government and the municipal government with the provincial funding gaining priority.

Student enrolment in the college was limited according to English performance. Namely, students who had received low English scores in the national matriculation English test could not enroll in the college. Each year 75 candidates were accepted by the college. Most students were recruited from senior middle schools in Zhejiang Province except a few who came from other provinces in China. Therefore, the students' English was comparatively better than that of other students in other colleges at the university.

\section{Data collection}

The BA English education program has not been evaluated before. The evaluation design involved two stages. In the first stage the data were col- 
lected, and in the second stage, the findings were analyzed. Considering Peacock's fifteen questions and the ideas of Chong and Cheah and Han and Zou, we compiled a questionnaire of ten questions so as we could investigate the program using quantitative data from the students involved in the program. Question 1 was about the pass rate of the TEM-4 and the TEM-8. Questions 2 to Question 6 were to test the pedagogic knowledge of the respondents. Question 7 and Question 8 were to test the respondents' reflections on changes in attitude toward teaching, self-identification and confidence after four years of pre-service training. The last two questions concerned comments on the courses they had been studying in the four years.

\section{Ethics}

Before beginning the research, a brief statement containing the research aims and questions, proposed methods of data generation and access to participants was discussed with the university research ethics coordinator.

An ethical consent form was discussed and signed by the cohort of participants. The form stated that pseudonyms would be used to refer to the participating institution and participants; participation was completely voluntary; participants were able to withdraw freely from the research at any time without risk or prejudice; their dignity and interests as research participants were respected at all times; they were assured that no harm would result from participating in the research; and in writing up the research report, the researcher was consistently cautious about the preserving anonymity; and further, to take anonymisation of individuals in order for them not to be identifiable, given that research findings may be presented to a variety of audiences.

\section{Results of the questionnaire}

The data from the questionnaires (see Appendix 1) are represented in Table 1 and Table 2, which reflect the information gathered from the questionnaires. 
Table 1

The results of the questionnaire

\begin{tabular}{lcccccccccc}
\hline $\begin{array}{l}\text { Questions } \\
\text { Choices }\end{array}$ & 1 & 2 & 3 & 4 & 5 & 6 & 7 & 8 & 9 & 10 \\
\hline $\mathrm{A}$ & 300 & & 40 & 240 & 100 & 40 & 10 & & 100 & 90 \\
\hline $\mathrm{B}$ & & 50 & 150 & 60 & 130 & 140 & 160 & 100 & 20 & 160 \\
\hline $\mathrm{C}$ & 50 & 50 & & 50 & 60 & 130 & 190 & 70 & 40 \\
\hline $\mathrm{D}$ & 200 & 60 & & 20 & 60 & & 10 & 110 & 10 \\
\hline
\end{tabular}

Table 2

The results of the questionnaire

\begin{tabular}{lcccccccccc}
\hline $\begin{array}{l}\text { Questions } \\
\text { Choices }\end{array}$ & 1 & 2 & 3 & 4 & 5 & 6 & 7 & 8 & 9 & 10 \\
\hline $\mathrm{A}$ & $100 \%$ & & $13.3 \%$ & $80 \%$ & $33.3 \%$ & $13.3 \%$ & $3.3 \%$ & & $33.3 \%$ & $30 \%$ \\
\hline $\mathrm{B}$ & $16.7 \%$ & $50 \%$ & $20 \%$ & $43.3 \%$ & $46.7 \%$ & $53.4 \%$ & $63.4 \%$ & $6.7 \%$ & $53.4 \%$ \\
\hline $\mathrm{C}$ & $16.7 \%$ & $16.7 \%$ & & $16.7 \%$ & $20 \%$ & $43.3 \%$ & $33.3 \%$ & $23.3 \%$ & $13.3 \%$ \\
\hline $\mathrm{D}$ & $66.6 \%$ & $20 \%$ & & $6.7 \%$ & $20 \%$ & & $3.3 \%$ & $36.7 \%$ & $3.3 \%$ \\
\hline
\end{tabular}

As shown in Table 1 and Table 2, all 300 respondents passed the TEM-4 test based on the National Syllabus for University English Majors administered in the fourth semester half way through the four-year program (MOE, 1985, 2000).

As also shown in Table 1 and Table 2, 28 of the 300 respondents passed the TEM- 8 administered in the eighth semester, the final semester of the program. $92.1 \%$ of the student teachers had passed it by the time they graduated. It was an indicator of the level of their English proficiency by the time they graduated from the program. Although the pass rate was lower than that of TEM-4, it was still certain that almost all had made great progress in listening, speaking, reading and writing skills since they did not stop attending classes. These results again confirmed that the cohorts of participants had good English competence.

Questions 2 to 6 were to test the pedagogic knowledge of the respondents. As shown in the two tables, over half of the respondents (66.6\%) did not know anything about the Task-based Language Teaching (TBLT) approach, from which we were able to see that the pedagogic knowledge instruction and/or learning in the pre-service education was not very successful. As a matter of fact, all the re- 
spondents had learnt something about TBLT when they were juniors. However, they only took tests to consolidate what they had learned instead of combining the theory with teaching practice. Therefore, when their finals came, most of the BA pre-service TEFL students had forgotten the pedagogic knowledge they had learned. As for the theory of Input Hypothesis, it was less theoretical than TBLT. Therefore, $50 \%$ of the respondents knew about it. When it came to the question regarding interaction, $80 \%$ of the respondents knew about it, which indicated that interaction was widely used in daily teaching, including in the teaching practice of university. That again confirmed that only when abstract theory was linked with practice could learners remember and understand it. About half of the respondents knew something about the learning curve they had learnt about in a course entitled Basic Principles of Education, since that was often mentioned by the their mentors in the class.

Questions 7 and 8 were to test the respondents' confidence after four years of pre-service teacher training. From the above tables, we found that most of the students had confident in themselves, which indicated that they had studied hard in the past four years. They believed they were capable of correcting students' mistakes and writing a good teaching plan. From the answers to Question 10, we predicted that most of the participants (85\%) were satisfied with the courses related to subject and content knowledge. From the answers to Question 9, we found that only a third of the participants were satisfied with the courses linking to pedagogic knowledge. Comparison with the answers to the last questions showed that the pedagogical related theories should be further strengthened.

Results of the semi-structured interviews

Patton (1990) suggests that focus group interviews are essential in the evaluation process. A sample that is balanced in terms of gender can help the interviewer obtain more comprehensive information. In this respect, the interviews achieved the most reliable results.

After randomly selecting subjects, we designed semi-structured interview questions (see Appendix 2). The first two questions concerned whether their attitudes towards teaching had changed after four years of education. The third one was designed to make clear how this change had taken place. The fourth related to whether they were ready to be lifelong elementary school teachers of English in rural primary schools. The last question was on classroom managerial competence.

Through these questions, we were trying to find out how their pre-service TEFL education had changed both them, in the course of becoming a pro- 
fessional teacher, and their attitudes toward being a 'teacher' for life. In the university library, we interviewed each subject in turn. After the interviews, we coded and then decoded the opinions of these 200 students on the basis of four themes according to the structured questions.

After the individual semi-interviews with the 200 student teachers, we took down the transcript of their answers for further analysis. The first two questions concerned their attitude toward teaching. The results are shown in the following table.

\begin{tabular}{llll}
\hline & Yes & No & Not so sure \\
4 years ago & $7(35 \%)$ & $4(20 \%)$ & $9(45 \%)$ \\
Now & $13(70 \%)$ & $2(10 \%)$ & $5(20 \%)$ \\
\hline
\end{tabular}

From the table we found that four years ago, most of the students had not been so sure about their future career and only $35 \%$ of the students had wanted to be a primary school teacher after graduation. Four years later, this situation had changed greatly. More than half of them were ready to be a primary school teacher though some of them would prefer to be a university lecturer rather than a primary school teacher. From the above data, we can conclude as follows:

Most of the students were not ready to be a teacher four years ago. Some of them questioned whether they were competent enough to become qualified teachers, while some had not considered becoming a professional teacher as their life career. Over half of them wanted to be a businessperson. Secondly, many students changed their attitude after the four-year pre-service education. They had acquired some pedagogical content knowledge and were willing to become involved in TEFL in primary schools in China. What had led to these changes? Through the semi-structured interviews, we found that various factors had contributed to these changes. Firstly, the people who they had contact with, such as the college teachers, and their evaluation of teaching had a great effect on the interviewees' choice. Here is what one interviewee said in the interview,

"I have been greatly impressed by Professor X, who teaches us listening. She is so elegant, so learned and so inspiring. She shows me that teaching is such a great job that once you dedicate yourself to it, you can get it done perfectly and influence lots of people. She is my idol and I'd like to be a teacher like her." 
Therefore, though her primary plan had been to work in commerce or finance, she was now ready to be a teacher. Secondly, students felt proud of themselves when they stood on the teaching platform and they supposed that teaching would mean they would be able to make both their lives and their future students' lives meaningful and extraordinary. The three-month practicum had benefitted them a lot. It had given them the opportunity to help others by teaching what they had learnt.

However, 200 interviewees complained that three months of teaching practice was insufficient given the weakness of the pre-service TEFL program. A very large proportion of them said that the program focused too much on the English language side instead of the teaching methodology side. They said that the program needed more on English teaching skills training to "equip us with the skills to deliver high-quality English teaching in pupils' real-life low-source classrooms". On the other hand, a very small proportion of them thought they were confident in their teaching abilities. Nonetheless $99 \%$ of them complained that the tutor's lecturing approach was either too academic in nature or tutor-centered which resulted in less consideration of the trainees' needs. One of them complained strongly, "you required us to involve the pupils' individual needs in lesson planning, while you seldom know our knowing and un knowing. This is strange, isn't?".

Regarding classroom managerial competence, $100 \%$ of the interviewees mentioned lack of input on classroom management skills as a program weakness. They reported that the skills linking building positive relationships with students, motivating students through incentives, decreasing inappropriate social behavior and properly using encouragement and praise skills are very practical. Lack of management skills might be a problem as Richards (1991) stated that discipline problems were fewer, motivation higher and learning more efficient in a well-managed class. Other weaknesses emerged included not enough on testing or educational technology; the methodology course was too theoretical and impractical since the instructor of the course was lacking in experience working in secondary or primary schools.

They claimed that the program lacked opportunities for practice. One interviewee said that although theory had its place in the program, practice was still needed. He gave an example, saying, "In writing classes, I were taught how to write but I were not taught how to teach the basic techniques to our students. "Views regarding the four-year courses were expressed by $90 \%$ of the interviewees who stated, for instance, that they were not able to forget the two periods of "School Experience" on mornings in which they observed 
mentor teachers and prepared micro-teaching sessions when they returned to their classrooms.

The strengths they mentioned were teachers being very kind and helpful and very easy to contact. Another strength voiced by four interviewees was that the students were allowed to decide on the content of some courses together with the teacher. The student teachers generally thought that the program was relevant to and met their needs. In this case, they felt that they were able to do the job well in the current Chinese socio-cultural context. In addition, the two vacations make the job very attractive and most of them said they were able to spend their time more flexibly and develop their own interests in the vacations. The available English teaching positions offered them no other better choices. All the students signed contracts with schools located in the downtown areas of cities in Zhejiang Province.

The interviewees also indicated factors of concern. For example, with the progression of age, they thought much more about what they were able to do rather than just what they wanted to do. They considered the meaning of their lives more, rather than simply seeing teaching as a job to make money. Many of them realized there were many other things to achieve in life and they gradually took to teaching as a job. More girls realized that they would have to take on duties, like having children and taking care of the family, which was why in the semi-structured interviews more girls chose to be teachers while more boys doubted their choices since they thought that teaching would make it harder for them to marry and support a family. However, this would surely be relevant to any teaching program - not just TEFL.

\section{Discussion}

\section{Pros and Cons}

The overall findings of this analysis are generally very positive regarding the BA TEFL program and suggest that, on the basis of the data, participation in the program led to increased use of positive behavior management strategies and an increase in teacher perceptions of the usefulness of these strategies. There were also high levels of satisfaction with the program with over $90 \%$ of interviewees providing positive ratings of: 1) the overall program; 2) the usefulness of teaching strategies; 3) specific teaching techniques.

The questionnaires and semi-structured interviews provided valuable data. They allowed us to evaluate the pre-service BA TEFL program from an in- 
sider's perspective and answer the research question. It is possible to use the results to make suggestions for improving the program as Peacock (2009) argues. The results might provide answers to unknowns in Zou's research (2009), whose findings was on the causes of the poor quality of a BA English education program through semi-structured interviews and other techniques.

In terms of knowledge of the English language, the study shows that four years of the pre-service teacher education program successfully improved their knowledge of English as a subject, as evidenced by the positive response to the question "Have you passed TEM 4/8?". This varies from student to student and it is uncertain whether they all made progress in acquiring listening, speaking, reading and writing skills.

According to the results of the questionnaire, $66 \%$ of the respondents do not know what TBLT is. It is worth mentioning that it is strongly recommended by STEP that TBLT be used in primary school English teaching in China nationally. This shows that such fancy terms as TBLT can be difficult to remember on one hand, and that emphasis on such knowledge is far from enough for pre-service English teacher training on the other. Respondents who say they do not know anything about TBLT may not be able to identify what the letters TBLT stand for, but when they go to give classes to secondary/primary school students in reality, there is a high probability that they will practice TBLT not knowing the term. Students may have subconsciously picked up practices used by teachers, when they were doing their practicum. As to the important role interaction plays in effective teaching, $80 \%$ of the respondents know the theory, according to the questionnaire. The high rate of positive answers to this question is due to teacher's emphasis on the theory and its widespread application in teaching practice. Now it is widely acknowledged that a class where the teacher lectures all the way through from the beginning to the end is outmoded, boring and ineffective.

Virtually all the lectures were academic in nature, and not much attention was given to teachers' needs when settling into their new school positions in terms of dealing with the practicalities of working with pupils and supporting them. When the will-be TEFL teachers did their teaching practice, this deep-rooted theory guided them, reinforcing their conscious practice of interaction theory. On their teaching practice, they found themselves in an artificial and difficult situation, and were consequently unable to assess adequately whether they would enjoy teaching. Collaboration between schools and colleges not only promises much for the training of teachers, but also there needs to be a closer examination of practices in schools. 
It is obviously essential for the college teachers involved in the four-year program that every care should be taken to ensure that the program is of benefit to school pupils. In a Chinese primary school, large classes of 40+ pupils are frequently seen. It also becomes apparent that the four-year program has to ensure benefits to the pupils, matching the proposed curriculum for the pupils in primary schools.

From the questionnaire, we can also perceive that most respondents feel confident that they can correct students' mistakes in use of English and design a good teaching plan. That their confidence may come from their ignorance about the great challenges in identifying and correcting students' mistakes or complacency in spending the whole four years at a comprehensive university is one thing; the enhancement of their confidence, regardless of their increased capability, is another, which cannot be denied. In boosting will-be teacher's confidence, the four years of pre-service education is generally successful.

With regard to change in attitude, most student teachers either hold a blind preference for teaching, or have no idea of what being a teacher means before entering into pre-service education. Unsurprisingly, after six years of cramming in junior and senior high school and with their eyes set solely on entering a prestigious university, few of them seriously consider their lifelong career. However, four years of TEFL pre-service education changed their attitudes toward teaching. According to the interview, a high figure, up to $70 \%$, of interviewees indicated that they want to be a teacher after graduation. Their reasons for this include their increased and comprehensive understanding of teaching as a career, the time and energy spent learning how to be a teacher, their growing maturity and responsibility to others and society, and their perception of their own limitations in being successful in other more demanding careers such as banker, manager and doctor. A large number of the respondents were more willing and prepared psychologically to take a teaching job. However, there are a few opposite cases. Their attitude towards teaching shifted from positive to rejecting teaching outright, as a result of their full perception of the high-input-andlow-output nature of teaching in terms of material returns, though being a teacher can bring other more rewarding and fulfilling returns. Whether their attitudes changed from "yes" to "no" or from "no" to "yes", the four years of pre-service education enabled them to make an informed judgment and take wise action in deciding whether to be a teacher. In this respect, the pre-service education plays its role and fulfills its purpose in increasing students' understanding of both themselves and teaching as a career. 
The role of the college lecturers should also change. They should move away from being providers of English knowledge to being facilitators of experience. Such a change becomes difficult to effect where there is no firm belief in the validity of programs of this nature. College teachers are responsible for helping student teachers to identify and understand the broader general theories underlying the teacher's craft, which the teachers feel influenced their future teaching practice.

As the conclusions from an internal examiner's report, this evaluation reveals certain area where improvements are possible and desirable. The program appears strong in teaching certain aspects of pedagogic skills and promoting teacher reflection and self-evaluation. Taken at face value these findings clearly suggest that the program achieved its primary objectives of increasing the level of teacher knowledge and competence in classroom behavior management. There are, however, some important limitations on the available data that need to be taken into account.

\section{Reflections}

Johnson and Golombek (2002) argue that any theory and any classroom methodology, or any description of English language as a subject matter must be understood against the backdrop of the trainees' academic lives. An absence of connection would mean only the learning of inert ideas (Whitehead, 1929), which remain passive in their minds and cannot serve to promote their understanding nor enhance their actual performance in class. Later on, Johnson and Golombek provide the following summary, "what they learn and how they use their knowledge in the classroom are highly interpretive and contingent on knowledge of self, students, curricula and setting. "In this sense, we need to know that the cohort does not simply pick up whatever the tutor says. They are accustomed to trying to digest whatever the tutor says by comparing and contrasting it with what is in their minds. The cohort, in that case, does not only possess knowledge, they are also able to be creators of knowledge of their own. This is of equal importance and legitimacy as that of the "expert" and theorists

So what we need to do next is to recognize the importance of personal knowledge and validate that by fusing it with the knowledge of the theorists because it takes as much effort and time, if not more, for the cohort to achieve that practical knowledge through trial and error. Therefore it is crucial to legitimize their voices in both academic discourse and theory construction before any serious learning can be expected and developed upon their newly- 
built understanding. As teacher trainers, what we need to do in the future is to help the cohort incorporate what is seen as outsiders' knowledge into what they consider to be their own knowledge, insiders' knowledge. By doing so, we can help them develop an understanding that they too will have their own theories about language learning and teaching. So the core concern becomes how we can help the cohort build up confidence in their own experiences and develop their own theories about teaching while trying to make sense of the theories of others. Based on this understanding, we argue that the BA program should include two important components. The first is reflection, and the second one is sharing through reflection. Individual reflection does not really allow what we expect will become their theory to emerge. It is only after sharing with others and trying to understand what has happened that individual reflection becomes meaningful, effective and empowering.

\section{Limitations}

A limitation to this study is that the sampling scales were not large enough to guarantee the objective and credible statistics needed to generalize the results of the study over this limited period of time, despite the research having been carried out over four years. A second weakness is that this research did not involve the program's course teachers. This was beyond the scope of the study since the program was a new one. However this missed step is an important one if we wish to improve the process in the future. We acknowledge that the pre-service TEFL program should incorporate a builtin procedure for teacher's internal evaluation and use it regularly.

\section{Conclusion}

In two ways, this research was conducted with the aim of discovering the influence the four-year pre-service BA TEFL program had on English major student teachers. On one hand, they have professional knowledge as all the respondents passed the TEM 4/8 tests. On the other hand, a less satisfactory finding was that though the student teachers had taken some classes about pedagogy, if it was not used or mentioned often, they forgot what they had learned, which shows the flaws in the four-year pre-service program.

With regard to student teachers' attitudes towards the four-year pre-service BA TEFL teaching, most of the interviewees came to understand that their odds of success would be greater if they became a teacher, which is a good thing. They were not only willing to teach but were also fully aware of what becoming a member of the teaching profession involves. 
These findings point to, on the one hand, the need for teacher educators to be both vigilant about the type of learning that is prescribed for the BA TEFL education program. Embedding coursework assessment in the practicum would arguably ensure that the pre-service student teachers' experience of integrating theory and practice is enhanced. On the other hand, teacher peers need to support students as they strive to implement meaningful, course-related teacher practices. Neither of these outcomes will occur without the establishment of strong school-university relationships, which provide the most proven vehicle for establishing and maintaining environments in which pre-novitiates can develop essential professional knowledge and skills.

\section{References}

Andrews, S. (2007). Teacher language awareness. Cambridge: Cambridge University Press.

Ball, S. J. (1999) Global trends in educational reform and the struggle for the soul of the teacher, paper presented at the British Educational Research Association Annual Conference, University of Sussex, Brighton, 2-5 September.

Brookes, W. (2005) The graduate teacher programme in England: Mentor training, quality assurance and the findings of inspection. Journal of In-Service Education, 31(1), 43-61.

Bryman, A. (2008). Social research methods (second edition). Oxford University Press. Burton, J. (2009). Reflective practice. In A. Burns, \& J. C. Richards (eds). The Cambridge Guide to Second Language Teacher Education (pp. 298-307). Cambridge: Cambridge University Press.

Candlin, C.N. (1998). General editor's preface. In P. Rea-Dickins, \& K. P. Cermaine, Managing evaluation and innovation in language teaching: building bridges. London: Longman.

Chong, S., \& Cheah, H. M. (2009). A values, skills and knowledge framework for initial teacher preparation programs. Australian Journal of Teacher Education, 34(3), 1-16.

Cohen, L., Manion, L., \& Morrison, K. (2011). Research methods in education. London: Routledge.

Cosgun-Ogeyik, M. (2009). Evaluation of english language teaching education curriculum by student teachers. Insan ve Toplum. 9(1), 42-57.

Darling-Hammond, L. (2006). Powerful teacher education: Lessons from exemplary programs. San Francisco, CA: Jossey-Bass.

Denscombe, M. (2010). The Good Research Guide: For small-scale social research projects. Maidenhead: Open University Press.

Educational Statistics Yearbook of China. (2014). Publisher: People's Education Press. Erozan, F. (2005). Evaluating the language improvement courses in the undergraduate ELT curriculum at Eastern Mediterranean University: A case study. Unpublished doctoral dissertation, Middle East Technical University, Ankara, Turkey.

Flick, U. (1998). An introduction to qualitative research. London: Sage. 
Freeman, D. (1996). The "unstudied problem": Research on teacher learning in language teaching. In D. Freeman, \& J. C. Richards (Eds.). Teacher learning in language teaching. New York: Cambridge University Press.

Freeman, D., \& Johnson, K. E. (1998). Re-conceptualizing the knowledge-base of language teacher education. TESOL Quarterly, 32(3), 397-417.

Furlong, J. (2000) School mentors and university tutors: Lessons from the English experiment. Theory into Practice, 39(1), 12-20.

Han, Y., (2010). The impact of pre-service teacher training on the later teaching performance. Teacher Education Study, 22(2), 134-144.

He, L., \& He, Z. (2012). Primary schoolteacher in China. Beijing: Education Press.

Johnson, K. E. (2006). The sociocultural turn and its challenges for second language teacher education. TESOL Quarterly, 4O(1), 235-257.

Johnson, K.E., \& Golombek, P.R. (Eds.) (2011) Research on second language teacher education: A sociocultural perspective on professional development. New York: Routledge.

Lim, C.P., \& Hang, D. (2003). An activity theory approach to research of ICT integration in Singapore schools computers and education. Retrieved December 15, 2008 from Academic Search Premier

http://www.library.dcu.ie/Eresources/databases-az.htm

Mackey, A., \& Gass, S. M. (2005). Second language research: Methodology and design. Mahwah, NJ: Lawrence Erlbaum Associates.

Ministry of Education, (2002). The concept of quality education: Key points for study. Beijing: People's Education Press.

Minott, M. A., \& Young, A. E. (2009). The benefits of employing a hybrid evaluation approach, enacted through evaluation survey and reflective journaling in teacher education in the Cayman Islands. Australian Journal of Teacher Education, 34(4), 16-26.

Partington, G. (2001). Qualitative research interviews: Identifying problems in technique. Issues In Educational Research, 11(2)|, 32-44.

Patton, M.Q. (1990). Qualitative evaluation and research methods. Newbury Park, CA: Sage.

Peacock, M. (2009). The evaluation of foreign-language-teacher education programs. Language Teaching Research, 13(3), 259-78.

Reid, J.M. (1996). Let's put the "T" back in TESL/TEFL programs. TESOL Matters, 5(6), 3.

Richards, J.C. (1990). The dilemma of teacher education in second language teaching. In J. C. Richards, \& D. Nunan (Eds.), Second language teacher education (pp.3-15). CUP. Richards, J. C. (2009). Competence and performance in language teaching. FLTED in China 2009 papers presented at $3^{\text {rd }}$ national symposium on foreign language teacher education and development. Beijing: Foreign language teaching and research press. Roberts, J. (1998). Language teacher education. London: Edward Arnold.

Seferoglu, G. (2006). Teacher candidates' reflections on some components of a pre-service English teacher education program in Turkey. Journal of Education for Teaching, 32(4), 369-378.

Smith, E., \& Reid, D. (2000) Considering the concept of the 'collaborative model' of the Secondary Post Graduate Certificate in Education Course, Mentoring \& Tutoring, $8(3), 251-259$. 
Wallace, M, J. (1991). Training foreign language teachers. CUP.

Wang, H. (2013). Teaching English in China. Beijing: People's Educational Press.

Wedell, M. (1992). Pre/in service training of ELT teacher trainer: Planning the regional MATEFL project. In J. Flowerdew, M. Brook, \& S. Hsia (Eds.), Perspectives on second language teacher education (pp.337-50). Hong Kong: City University of Hong Kong.

Wei, R.C., \& Pecheone, L. (2010) Assessment for Learning in pre-service teacher education performance-based assessments. In M. M. Kennedy (Ed.). Teacher assessment and the quest for teacher quality. San Francisco Co: Cambridge University Press. Jossey Bass.

Weiss, R. S. (1994). Learning from strangers, the art and method of qualitative interview studies. New York, NY: Free Pr.

Williams, A., \& Soares, A. (2002) Sharing roles and responsibilities in initial teacher training: Perceptions of some key players, Cambridge Journal of Education, 32(1), 91-107.

Zou, W. (2009). The study on the pre-service teacher education for Chinese basic education. Foreign language teaching theory and practice, 4(1).

\section{Author:}

Wang Ping, Associate Professor

Jiaxing University

College of Foreign Languages

56 Yuexiu Road (South)

Jiaxing, Zhejiang Province

314001

China

Email: pwang886@hotmail.com 


\section{APPENDICES}

\section{Appendix 1: Questionnaire}

Hey everyone! I am working on a study about the evaluation of xxxx-class program evaluation. So I will appreciate it if you can accomplish this questionnaire. Thank you for your time.

Age ranges: A: 19-20; B: 20-22; C: 22-25; D: over 25 Gender: A: female; B: male C: other

The purpose of this survey is to assess the quality of the academic programs.

Part I. Please evaluate the listed courses you have had in the past four years.

A: Very satisfied

B: Satisfied

C: Medium

D: Not satisfied

1. Advanced General English

2. American Culture and Society

3. British Culture and Society

4. British \& American Literature

5. Basic Principles of Education

6. EAP Reading

7. EAP Listening

8. EAP Writing

9. Grammar A

10. Integrated English

11. Intercultural Communication

12. Linguistic

13. Listening

14. Methodology

15. Newspaper reading

16. Other selective courses

17. Psychology

18. Speaking

19. Translation

20. Writing 
Part II. Please choose the proper answer(s) to the following questions.

21. Have you passed the Test for English Majors (TEM)? If yes, choose the answers from $\mathrm{A}, \mathrm{B}$, or $\mathrm{C}$. If not yet, you may choose D.

A: TEM 4; B: TEM 8; C: Both; D: None

22. We have learnt an approach in the teaching methodology course: TBLT. What is the notion of TBLT?

A: I definitely know it; B: I know it; C: Partly D: I have no idea if it.

23. In linguistics the teacher talked about the second acquisition. Input hypothesis is one of the terms. Can you explain it?

A: Off course, I can; B: Partly yes; C: Not sure; D: Sorry I cannot.

24. Do you know what roles Classroom Interaction play? If yes, please illustrate them in brief.

A: Off course, I do; B: Partly yes; C: Not sure; D: Sorry I do not.

25. Can you explain the Inter-language theory coined by Selinker?

A: Off course, I can; B: Partly yes; C: Not sure; D: Sorry I cannot.

26. Can you explain the function of Pygmalion Effect in your own words?

A: Off course, I can; B: Partly yes; C: Not sure; D: Sorry I cannot.

27. Are you capable of correcting students written mistakes?

A: Off course, I am; B: Largely yes; C: Not sure; D: Sorry I do not know.

28. Can you feel confident in designing a lesson plan?

A: Off course, I can; B: Largely yes; C: Not sure; D: Sorry I cannot.

29. Are you satisfied with the courses linking to pedagogical knowledge in general?

A: Off course, I am; B: Largely yes; C: Not very; D: Sorry I am not.

30. Are you satisfied with the courses related to subject knowledge and content knowledge in general?

A: Yes, both; B: Largely I like both of them; C: only one; D: Sorry I am not.

\section{Appendix 2: Interview questions}

1. What attitude did you have when you started to be involved in the TEFL program in the university?

2. What attitude do you hold toward the program now?

3. How have you changed so much in attitude toward the program?

4. Do you prefer to treat teaching as your life-long career?

5. After the 3-month internship, do you think if you can effectively manage your classroom teaching and learning? And do you think if you have transitioned through the pre-service program and into the workplace?

If you would like to, you can make any general comments for the course you have learnt. And hopefully you can talk about the internship issues or something you have interest in. 